Western North American Naturalist 70(3), (C) 2010, pp. 418-420

\title{
FIRST RECORD OF A RANGE EXTENSION OF THE CLIFF CHIPMUNK (TAMIAS DORSALIS) INTO THE HUACHUCA MOUNTAINS
}

\author{
Nichole L. Cudworth ${ }^{1,2}$ and John L. Koprowski ${ }^{1}$
}

\begin{abstract}
Chipmunks are widely distributed throughout the mountain ranges of Arizona. However, no living chipmunks are known from the Huachuca Mountains despite the availability of favorable habitat. Based upon pelage characteristics of captured individuals, we provide the first report of a breeding population of cliff chipmunks (Tamias dorsalis) in the Huachuca Mountains and discuss possible mechanisms of their arrival.
\end{abstract}

Key words: Arizona, cliff chipmunk, distribution, Huachuca Mountains, Tamias dorsalis.

Chipmunks (Tamias) are widely distributed throughout the mountain ranges of Arizona (Hoffmeister 1986). Despite a number of surveys over the past century (e.g., Allen 1895, Mearns 1907, Hoffmeister and Goodpaster 1954) and the availability of favorable habitat in the Huachuca Mountains, Cochise County, Arizona, no breeding populations of chipmunk have ever been documented — an absence which Mearns (1907) noted as "remarkable." The Huachuca Mountains, approximately 26,000 ha in area and varying from 1500 to $2880 \mathrm{~m}$ in elevation, encompass a diversity of vegetation types and exhibit a correspondingly rich diversity of 75 species of mammals. This diversity is due, in part, to the position of the mountain range at the northern or southern range limit of many species (Hoffmeister and Goodpaster 1954).

Cliff chipmunks (Tamias dorsalis) have a fragmented range in southeastern Arizona and are known from other comparable ranges to the north (Pinaleño Mountains, $137 \mathrm{~km}$ ), east (Chiricahua Mountains, $111 \mathrm{~km}$ ), northwest (Santa Catalina and Rincon mountains, $78 \mathrm{~km}$ ), and far south in coastal Sonora (Callahan and Davis 1977, Hoffmeister 1986). In 2003, a decomposing carcass identified as a cliff chipmunk was found in a cave in the Huachuca's Sheelite Canyon (Sidner and Stone 2005). Herein we provide the first account of a breeding population of cliff chipmunks in the Huachuca Mountains.

We observed cliff chipmunks calling and moving among rocks of a dry stream bed in the upper Ramsey Canyon drainage of the Huachuca Mountains (elevation 1900 m; Fig. 1) on more than 3 occasions in spring 2007. To verify presence and identification, we captured 2 individuals in Tomahawk (Tomahawk Live Trap Co., Tomahawk, WI) and Sherman (H.B. Sherman Traps, Tallahassee, FL) live traps baited with peanut butter and peanuts near rocky outcroppings on 7 July and 7 August 2007. We transferred animals to a cloth handling cone (Koprowski 2002) and recorded sex, age class, mass, and reproductive condition. We collected hair from and eartagged (model 1005-3, National Band and Tag Co., Newport, KY) and photographed each individual before release (Fig. 1). The first individual was a potentially pregnant adult female with a body mass of $80 \mathrm{~g}$; the other captured female had a body mass of $75 \mathrm{~g}$ and had recently completed lactation, as evidenced by distended and darkened teats with surrounding hair loss. Because the current status of the population in the Huachuca Mountains is unknown, we did not acquire a voucher specimen at this time. However, the gray dorsum with indistinct body stripes and dark middorsal stripe is unique among chipmunks in Arizona (Hoffmeister 1986; Fig. 1), and measurements on the carcass found by Sidner and Stone (2005) further support identification as T. dorsalis.

Our recent discovery of a breeding population of cliff chipmunks in the Huachucas may simply reflect a human introduction. Alternatively, our discovery may be among the first

\footnotetext{
${ }^{1}$ Wildlife Conservation and Management, School of Natural Resources and the Environment, The University of Arizona, Tucson, AZ 85721.

2E-mail: ncudwo@gmail.com
} 


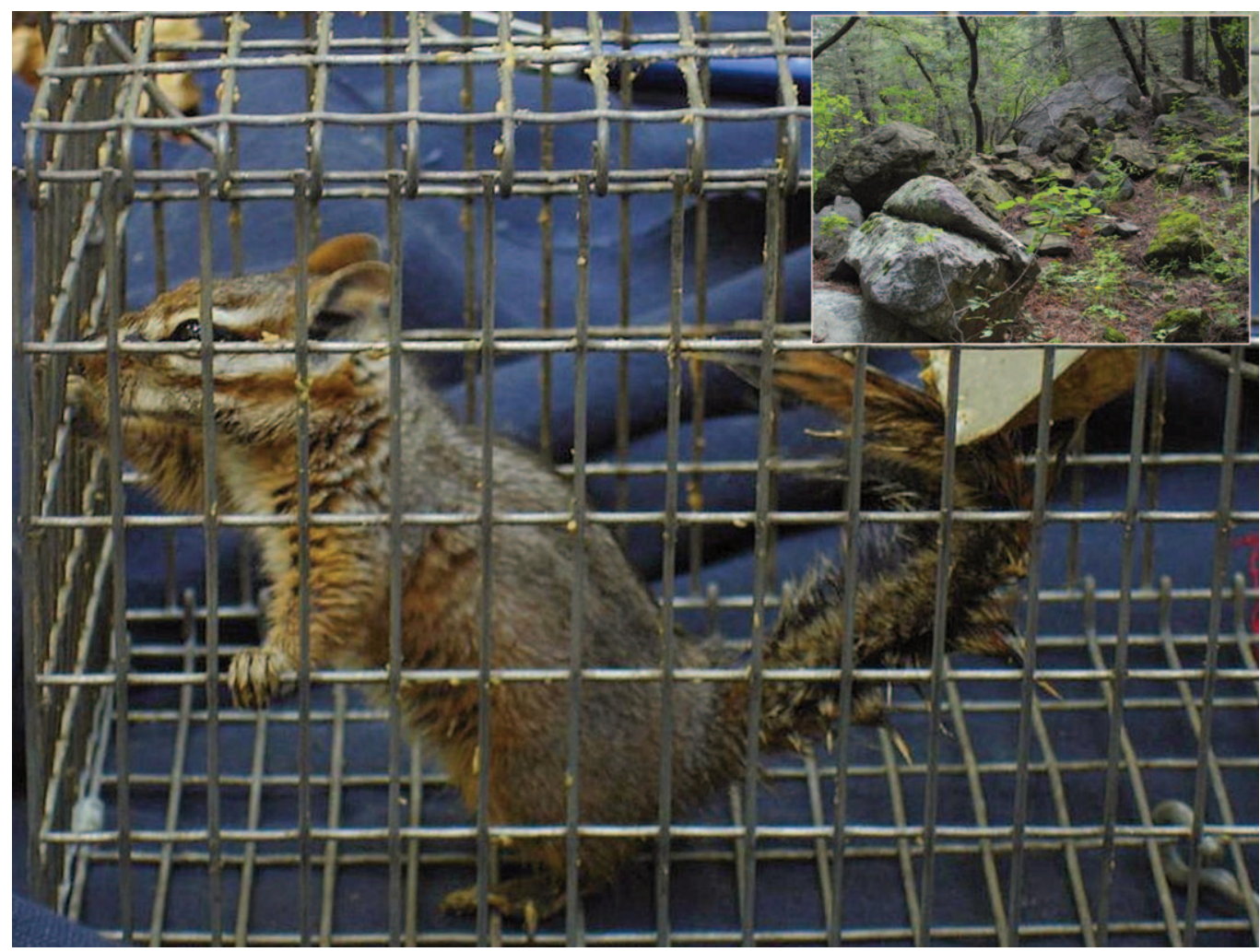

Fig. 1. Adult female cliff chipmunk (Tamias dorsalis) captured 7 July 2007 in the upper Ramsey Canyon drainage of the Huachuca Mountains, Cochise County, Arizona (elevation 1900 m; inset).

records of a relict population overlooked in previous mammalian surveys or may suggest colonization from a neighboring population (Sidner and Stone 2005). The Huachucas are one of the most isolated mountain ranges in southeastern Arizona (Hoffmeister and Goodpaster 1954), with the nearest source population of cliff chipmunk $78 \mathrm{~km}$ away in the Rincon Mountains (Sidner and Stone 2005). The 2 mountain ranges are separated by a mixture of chaparral and grassland communities (Lomolino et al. 1989). Cliff chipmunks typically occupy montane habitats at elevations between 1500 and $3700 \mathrm{~m}$ (Callahan and Davis 1976, Hart 1992), and elevations between ranges may be as low as $1100 \mathrm{~m}$. Consequently, recent dispersal between mountain ranges in southern Arizona may be quite limited. Additionally, the multiple references by Mearns (1907) to the shy and timid behavior of cliff chipmunks may further support representation of the Huachuca population as a relict population that has only recently been discovered. However, the open woodlands and grasslands between mountains may provide a permeable barrier, potentially serving as a corridor for small mammal dispersal (Davis et al. 1988). For example, the current distributions of yellow-nosed cotton rat (Sigmodon ochrognathus: Davis and Dunford 1987), Abert's squirrel (Sciurus aberti: Davis and Brown 1989), and Mexican vole (Microtus mexicanus: Davis and Callahan 1992) likely resulted from northward expansion due to recent dispersal (but see Frey 2008); chipmunk populations throughout the mountain ranges surrounding the Huachucas (Hoffmeister 1986) may follow similar routes.

Future studies should focus on the genetic structure of the Huachuca cliff chipmunk population to provide insight on the relative contributions of gene flow and genetic drift, potential populations from which the Huachuca chipmunks originated, method of colonization, and length of time since isolation in the range. Such analyses could assess when cliff chipmunks arrived in the Huachuca Mountains and whether 
the Huachuca Mountain population resulted from recent dispersal (Sidner and Stone 2005) or a historical population that may have differentiated from other populations. Additional studies on population structure and distribution will determine the current status and conservation needs of this population. Comparisons of the Huachuca Mountain population with populations in neighboring mountain ranges will provide information on levels of genetic differentiation. These studies will further increase our understanding of factors shaping current mammalian distributions among mountain islands in the American Southwest.

We wish to thank Liz Baker for her assistance in trapping and data collection and Brooke Gebow and the Ramsey Canyon Nature Preserve of the Nature Conservancy for housing and logistical support. E.A. Arenas, J. Frey, J.P. Hubbard, and 3 anonymous reviewers provided helpful comments on earlier drafts. The Arizona Game and Fish Department provided funding for the overarching study on Arizona gray squirrels in the Huachucas, and the Department of Defense-Fort Huachuca Military Reservation and the University of Arizona provided live traps.

\section{Literature Cited}

Allen, J.A. 1895. On a collection of mammals from Arizona and Mexico, made by Mr. W.W. Price, with field notes by the collector. Science 2:417-418.

Callahan, J.R., AND R. Davis. 1976. Desert chipmunks. Southwestern Naturalist 21:127-130.

. 1977. A new subspecies of the cliff chipmunk from coastal Sonora Mexico. Southwestern Naturalist 22:67-75.
Davis, R., AND D.E. Brown. 1989. Role of post-Pleistocene dispersal in determining the modern distribution of Abert's squirrel. Great Basin Naturalist 49:425-434.

Davis, R., and J.R. Callahan. 1992. Post-Pleistocene dispersal in the Mexican vole (Microtus mexicanus): an example of an apparent trend in the distribution of Southwestern mammals. Great Basin Naturalist 52: 262-268.

Davis, R., AND C. Dunford. 1987. An example of contemporary colonization of montane islands by small, nonflying mammals in the American Southwest. American Naturalist 129:398-406.

Davis, R., C. Dunford, and M.V. Lomolino. 1988. Montane mammals of the American Southwest: the possible influence of post-Pleistocene colonization. Journal of Biogeography 15:841-848.

FREY, J.K. 2008. Distinguishing range expansions from previously undocumented populations using background data from museum records. Diversity and Distributions 15:183-187.

HaRT, E.B. 1992. Tamias dorsalis. Mammalian Species 399: $1-6$.

Hoffmeister, D.F. 1986. Mammals of Arizona. University of Arizona Press, Tucson, AZ.

Hoffmeister, D.F., and W.W. Goodpaster. 1954. The mammals of the Huachuca Mountains, southeastern Arizona. Illinois Biological Monographs 24:1-152.

KoprowsKI, J.L. 2002. Handling tree squirrels with a safe and efficient restraint. Wildlife Society Bulletin 30: $101-103$.

Lomolino, M.V., J.H. Brown, And R. Davis. 1989. Island biogeography of montane forest mammals in the American Southwest. Ecology 70:180-194.

MeARns, E.A. 1907. Mammals of the Mexican boundary of the United States. Bulletin of the United States National Museum 56:1-530.

Sidner, R., AND H.S. STONE. 2005. First records of two species of mammals in the Huachuca Mountains: results of ecological stewardship at Fort Huachuca. Pages 131-134 in USDA Forest Service Proceedings RMRS-P36.

Received 4 March 2009 Accepted 2 April 2010 